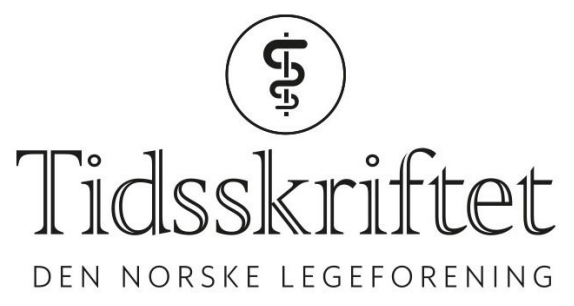

\title{
Den søte melk når motgang svir din hud
}

TIDLIGERE I TIDSSKRIFTET

TONE BERGSET

E-post: tone.bergset@legeforeningen.no

For de fleste er det nok ikke motgang som fører til en hudsykdom. Veldig mange hudlidelser er medfødte, og det gjelder også lidelsen til vår 12-årige pasient i denne kasuistikken fra 1937 (Tidsskr Nor Lægeforen 1937; 57: 191-94). 


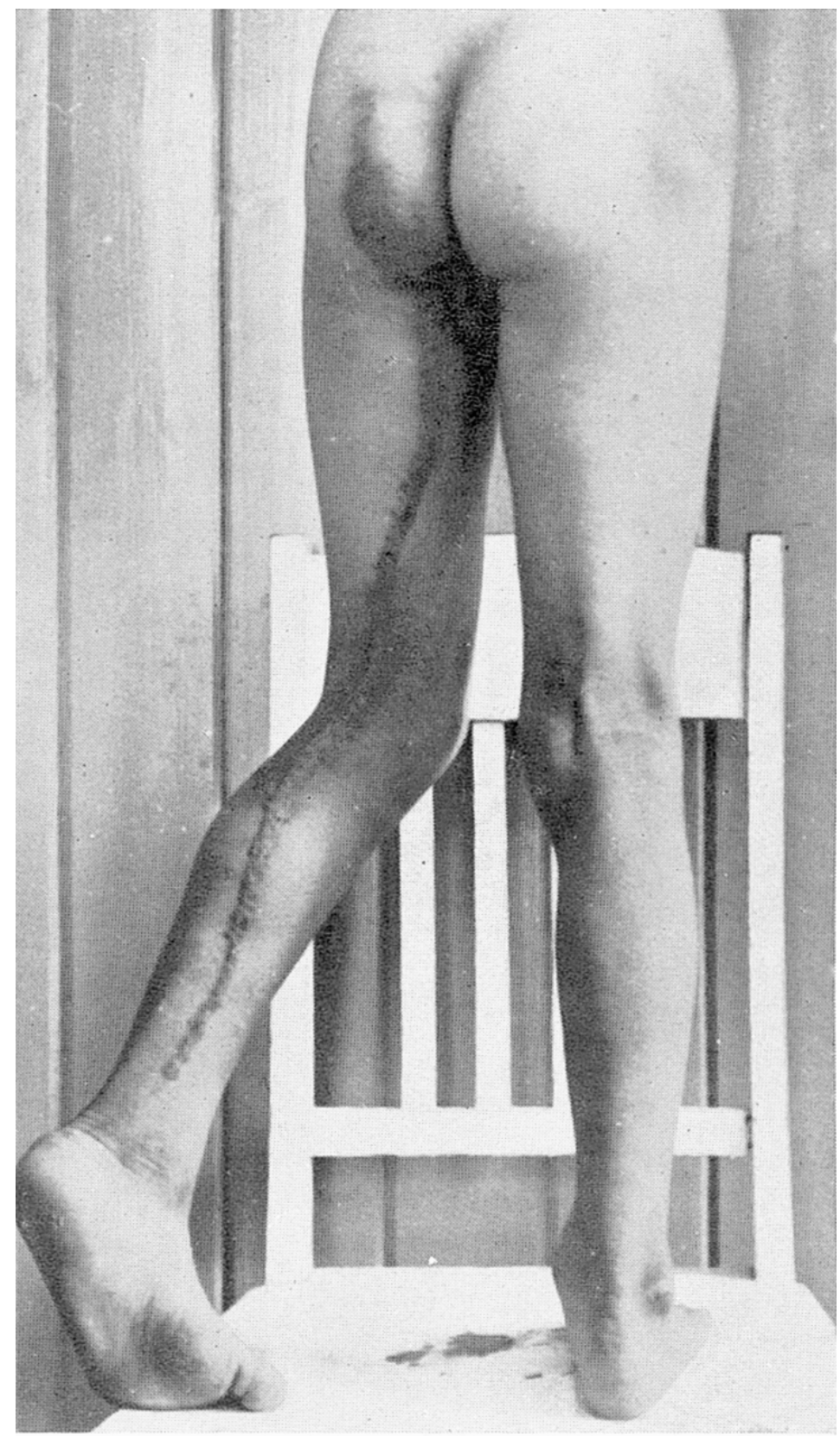

\section{Nævus linearis.}

\section{Av H. P. Petersen, Østby-Trysil}

De såkalte nævi lineares pleier alltid på grunn av sin eiendommelige form og utbredelse å vekke en viss interesse. Ser man nøiere efter vil man nemlig opdage at disse lineære lidelser markerer grensen mellem to hudnervers innervasjon. (...) Det efterfølgende kasus vil vise dette.

Patienten er en 12 år gammel gutt i hvis slekt det ikke er nogen sykdommer, bortsett fra en faster som angivelig er død av lepra for en del år tilbake. Patientens hudlidelse er et tilfeldig fund, han har aldri søkt læge for sin hudlidelse. Patientens foreldre oplyser at han er født med sin hudlidelse. Ved fødselen viste den sig som en stripeformig «føflekk» i fossa poplitea, strekkende sig op til midt på læret og nedover til midt på leggen. Den var da i hele sin utstrekning i hudens nivå. Efter hvert tiltok den i størrelse, idet den trakk sig lenger nedover leggen og op på nates. Det klødde litt i den, særlig når han blev varm. Litt efter litt blev den nuppet og vortelignende med enkelte skjell. Men den har hele tiden holdt sig som en smal stripe, aldri bredt sig ut til sidene. Sitt nuværende utseende har den hatt de siste 6-7 år. Som det vil fremgå av figur 1, består eksantemet av et 10-15 mm. bredt bånd, som strekker sig fra leggens nedre tredjedel, opover til den mediale del av fossa poplitea, videre langs innsiden av låret og op nates, hvor det slutter bratt. (...) 
Det blev ekscidert et lite stykke av eksamentemet nederst på leggen og sendt inn til mikroskopisk undersøkelse på Patologisk-anatomisk institutt. Det gav følgende resultat:

«Mikr. sees en epidermis med store hyperplastiske papiller ned i corium. Papillene er alle vel begrenset. I corium sees flekkvise små mononukleære betendelsesinfiltrater uten noget spesifikt særpreg. Der er betydelige hyperkeratotiske påleiringer på epidermis.

Diagnose: Hud med epitelhyperplasi og hyperkeratose, med lette dermatitiske forandringer.

For professor Harbitz

Roar Strøm»

Publisert: 2. oktober 2017. Tidsskr Nor Legeforen. DOI:10.4045/tidsskr.17.0745

(C) Tidsskrift for Den norske legeforening 2020. Lastet ned fra tidsskriftet.no 